\title{
Selective effect of terpenes on wood-decomposing Hymenomycetes
}

\author{
Veikko Hintikka \\ The National Research Council for Agriculture and Forestry \\ and Finnish Forest Research Institute, Unioninkatu $40 \mathrm{~A}$, \\ Helsinki 17, Finland
}

\begin{abstract}
The terpene tolerance of 16 species of Hymenomycetes occurring in nature in coniferous wood and that of 22 species growing in the wood of deciduous trees was studied by growing these on $1 \%$ malt agar in closed desiccators into which measured amounts of the following terpenes were pipetted: $\alpha$-pinene, $\beta$-pinene, limonene, camphene, or 3 -carene. The corculation of the air within the desiccator was effected by means of a propeller. Most of the conifer species investigated were able to grow in the saturated atmospheres of these terpenes. In contrast, small amounts of terpenes already present in the air inhibited the growth of species occurring in the wood of deciduous trees. Judging from a survey of pertinent literature, the amount of terpenes in conifer wood is enough to saturate at least part of the atmosphere within living tree trunks. Evidently the terpenes in conifer wood have a selective effect on invading fungus populations through a 》claustrogaseous effect» owing to the dense structure of the wood.
\end{abstract}

\section{Introduction}

One of the most conspicuous and constant phenomena in the biology of wood-decomposing basidiomycetes is the restriction of some species exclusively to the wood of conifers and of other species to the wood of deciduous trees, a fact which is often used as an important taxonomic characteristic of the species. In explaining this type of distribution, one must know the actual conditions prevailing within the wood of different trees at the time of fungus penetration as well as their effects on the physiology of the fungus. If we ignore the anatomical structure of wood, one of the major differences between coniferous wood and that of deciduous trees lies in the presence of oleoresins in the coniferous wood.

Since the last century resins have been regarded as important in the tree:decay fungus interactions which were recently especially emphasized by Gribs (1968). Resin, which consists of resin acids and different terpenes, is exuded in resin ducts, which are distributed as a more or less interconnected network throughout the whole tree although there is a great variety of differences in distribution between the tree species. According to Murto (1951) and JuvoneN (1966) pine wood contains up to $20 \%$ resin depending upon the part of the tree. The content of pathological resin is much higher in the wood cavities and around wounds. In resin tapping, a pine tree of $30-40 \mathrm{~cm}$ d.b.h. may produce $4 \mathrm{~kg}$ of resin a year (KALELA 1946). The oleoresin of Finnish pine contains up to $20 \%$ terpenes, the most important of which are alpha pinene, beta pinene, 3-carene, camphene, beta phellandrene, limonene and myrcene, which make up about $70-80 \%$ of the pine oil (JuvoneN 1966). The composition of terpenes varies to some extent with regard to seasons, different 
parts of the tree, weather conditions and different pine populations, but in general the same components are dominant. In other species of Pinus these same compounds are commonly met with (Mrrov 1961).

The stem wood of Picea abies contains ca. $0.3 \%$ oil per dry weight of the wood, and the main components are limonene (33\%), alpha pinene $(25 \%)$, beta pinene and beta phellandrene; roots contain, in addition, santene and bornylacetate (Schantz \& JuvoneN 1966).

According to CoBb et al. (1968) air saturated with alpha pinene contains approxi- mately $18 \mathrm{mg} / \mathrm{l}, \quad \beta$-pinene $\Delta^{3}$-carene and limonene $6-8 \mathrm{mg} / \mathrm{l}$. If we calculate the actual content of terpenes in pine and spruce wood from the above values, we find that there is enough to saturate the gas phase of the tree with these substances, providing we allow for diffusion across cell walls (KISSER 1958). At least the air below wound surfaces covered with resin would be saturated with terpenes. Thus fungi, which in nature grow within tree trunks or penetrate through wounds or conifer bark, should be able to tolerate high concentrations of terpenes in the gas phase.

\section{Methods}

Fungus strains cultured in the Forest Biology Laboratories of the Finnish Forest Research Institute were used in this investigation. The strains were isolated in Finland during the years 196569. and were kept on agar slants at $+5^{\circ} \mathrm{C}$ with approximately two transfers a year. The strains were inoculated into $9 \mathrm{~cm}$ or $6 \mathrm{~cm}$ petri dishes on $1.5 \%$ Difco malt extract agar, and the dishes were placed, without lids, upside down in empty 101 desiccators. Measured amounts of terpenes were pipetted into the desiccator and the desiccator was immediately closed. Preliminary experiments indicated that circulation of the air within the desiccator was necessary and this was effected by an iron propeller driven by a magnetic stirrer (Fig. 1) for approximately two hours a day at ca. 200-300 rotations per minute. The experiments lasted for 8-10 days. The desiccators were kept at room temperature in a room whithout windows. When the amount of terpenes needed to saturate the air in the desiccator with a propeller was determined, values were obtained that were about 4 times higher than those given by Совв et al. (1968). Although small changes in temperature could not be avoided, condensation of terpenes on the mycelium was not observed. The following monoterpenes were used: (+) camphene (Fluka AG., techn.), $\Delta^{3}$-carene (Koch-Light Lab. Ltd., pract.), (+)-limonene (Fluka AG., purum), $\alpha$-pinene (Fluka AG., pract.) and $\beta$-pinene (Fluka AG., pract.). Table 1 shows the radial growth of the strains in $\mathrm{mm}$. The concentrations are given in $\%$ ( $\mathrm{ml}$ liquid pinene/ml air).

\section{Results and Discussion}

In general, fungi from coniferous wood proved to be tolerant to high concentrations of terpenes in the gas phase. This is especially true with regard to species which in nature grow within conifer stems, e.g. Fomitopsis annosa, (causes heart rot in spruces), Phellinus pini (in pine heart wood), Stereum sanguinolentum (causes top rot in spruce), and Fomitopsis pinicola. Coriolellus serialis, Gloeophyllum (Lenzites) sepiarium, and Fomitopsis rosea, which of ten grow on dead and weathered wood, showed a slightly lower tolerance. Xeromphalina campanella, Gymnopilus penetrans and Coriolus vaporarius, which are met with on wood in advanced decay, had a considerably lower tolerance than the species just mentioned. It is interesting to note that Lentinus lepideus, which is otherwise highly tolerant to e.g. creosote, proves to be more sensitive to terpenes than the parasitic species.

Among species which in nature grow in the wood of deciduous trees there were practically none which were able to stand up to atmospheres saturated with terpenes, and a total inhibition set in at definitely lower concentrations than in the case of typical coniferous wood species. The most tolerant ones 
were Flammulina velutipes, which grew very slowly in atmospheres saturated with $\alpha_{-}$and $\beta$-pinene and Daedalea quercina.

In Table 1 the species are divided into two groups depending upon whether they grow in Finland mainly on the wood of deciduous trees or on coniferous wood. However, in Central Europe many species have a greater variety of hosts than in Finland. E.g. Laetiporus sulphureus, which is found mostly on oak wood Finland, is met with in Central Europe on coniferous wood too (KREISEL 1961). On the basis of this study it is not possible to conclude whether this phenomenon is due to different physiological strains of the fungus or to different substrates.

Of the species listed in Table 1, Fomitopsis pinicola, although a typical coniferous wood species, also often grows on the wood of deciduous trees. This may be due to different physiological strains. In order to study this phenomenon, $F$. pinicola was isolated from pine, spruce, Tilia, Betula, and Alnus incana, and tested for tolerance to $\alpha$-pinene, but no significant differences were found. In the Soviet Union, Suvorov (1967) has not been able to find different strains of this fungus, either.

When the effects of different terpenes were compared, limonene proved to be the most toxic to fungal growth. According to Asplund (1958) limonene is more toxic to germinating seeds of higher plants than pinenes. None of the terpenes investigated inhibites completely the growth of Fomitopsis annosa, which is an extremely harmful tree parasite in Finland. As there are many other terpenes and volatile compounds present in the oleoresin of conifers, it would be interesting to investigate whether there are more fungistatic compounds among these compounds.

The concept of gaseous inhibition, as well as that of stimulation, is well established in fungal ecology (Norrman \& Fries 1967). Volatile plant substances affect the micro-organisms in the soil (RoBiNson \& Park 1966, Menzies \& Gilbert 1967, Gilbert et al. 1969) and the bacteria found on leaves (Smirnoff 1968). Among woodinhabiting fungi, the well-known investigations of Suolahti (1951) suggest gaseous stimulants in fresh wood. Shrimpton \& WHITNEY (1968) have found that volatile extracts of resinous wood inhibit the growth of blue stain fungi. Cовв et al. (1968) have

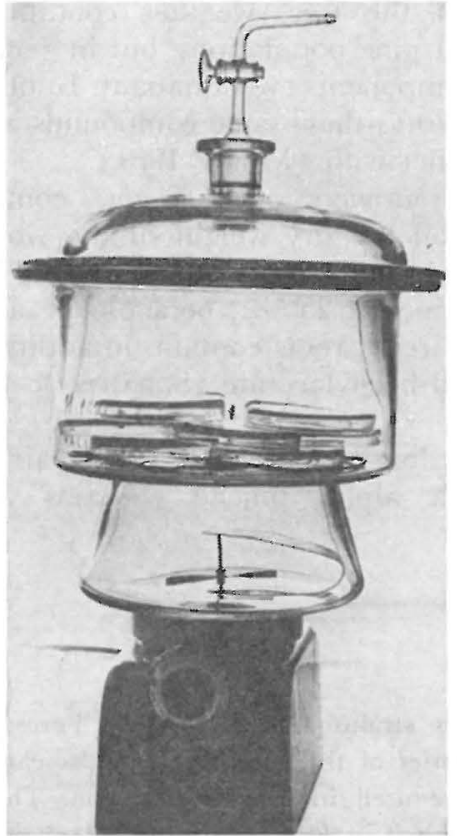

Fig. 1. Layout of the experiment.

studied the response of Fomitopsis annosa as well as of three blue stain fungi to atmospheres saturated with different terpenes occurring in coniferous wood. Especially among the latter, the tolerance was correlated with the habitat, the saprophytic species being the most tolerant, and species inhabiting the burrows of bark beetles the least tolerant. $F$. annosa proved, just as it did in the present investigation, capable of growing in saturated atmospheres.

In general the ventilation of the soil seems to be considerably greater than that of wood, which is evident e.g. in the accumulation of carbon dioxide in wood (THacker \& Good 1952, Jensen 1969, Hintikka \& Korhonen 1970). In volatile inhibition, Robinson \& PARK (1966) have emphasized the importance of »sealed conditions». Accordingly, in the distribution of fungiakind of $\gg$ claustrogaseous effect» seems present to some extent. This means that in wood and other compact structures volatile metabolites and excretions may accumulate in toxic concentrations, although the actual quantities may be extremely small. In more loose substrates, like forest humus and litter, ventilation and diffusion prevent accumulation. In sterilization by heat or volatile chemicals the terpenes are easily lost, thus changing the properties of the wood for invading micro-organisms. 
Table 1. The effect of different terpenes on the radial growth of wood-decomposing Hymenomycetes.

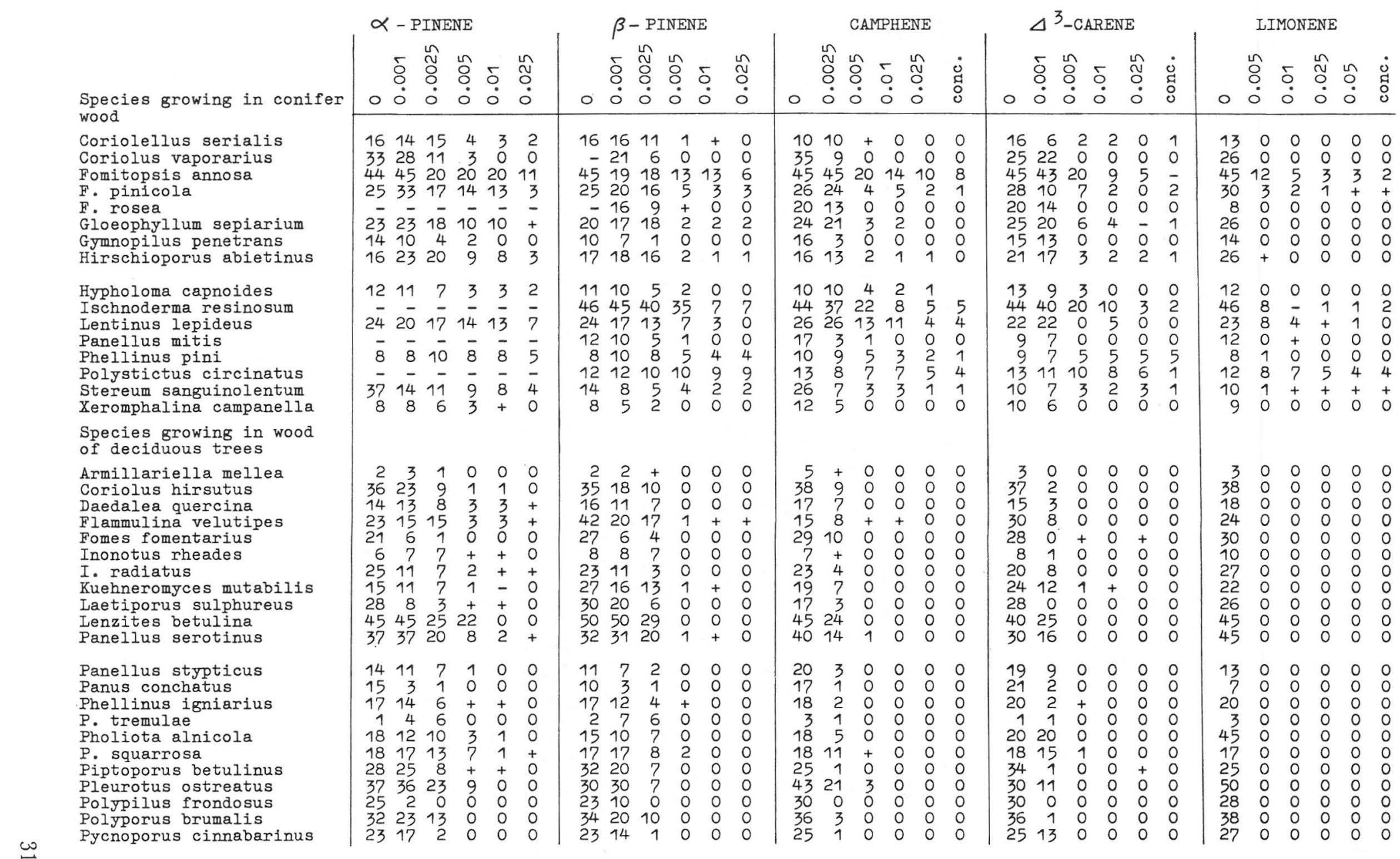


This study was carried out at the Finnish Forest Research Institute under a grant from the Nation- al Research Council for Agriculture and Forestry.

\section{REFERENGES}

Asplund, R. O., 1968: Monoterpenes:relationships between structure and inhibition of germination. - Phytochemistry 7, 1995-1997.

Сobb, F. W. Jr., M. Krstic, E. Zavarin \& H. W. BARBER Jr., 1968: Inhibitory effects of volatile oleoresin components of Fomes annosus and four Ceratocystis species. - Phytopathology 58, 1327-1335.

Grbss, J. N., 1968: Resin and the resistance of conifers to Fomes annosus. - Annals of Botany 32, 649-665.

Gilbert, R. G., J. D. Menzies \& G. E. Griebèt 1969: The influence of volatiles from alfalfa upon growth and survival of soil microorganisms. - Phytopathology 59, 992995.

Hintikka, V. \& K. Korhonen, 19:70: Effects of carbon dioxide on the growth of lignicolous and soil-inhabiting Hymenomycetes. Commun. Inst. Forestalis Fenniae 69(5), 1 -29 .

Jensen, K. F. 1969: Oxygen and carbon dioxide concentrations in sound and decaying red oak trees. - Forest Science 15, 246-251.

Juvonen, S., 19:66: Über die die Terpenbiosynthese beeinflussenden Faktoren in Pinus silvestris L. - Acta Botanica Fennica 71, 1-92.

Kalela, E. K., 1946: Pihkomiskokeita pohjoisissa männiköissä. (Ref. Harzgewinnungsversuche in nordischen Kiefernwaldungen.). - Acta Forestalia Fennica 52: 3, $1-39$.

Kisser, J. G., 1958: Die Ausscheidungen von ätherischen Ölen und Harzen. - Handbuch der Pflanzenphysiologie, herausg. von W. Ruhland, Band X, 91-131.

KreIseL, H., 1961: Die phytopathogenen Grosspilze Deutschlands. - 284 pp. Jena.

Menzies, J. D. \& R. G. Gilbert, 1967: Responses of the soil microflora to volatile components in plant residue. - Soil. Sc. Soc. Am. Proc. 31, 495-496.
Mrrov, N. T., 1961: Composition of gum turpentines of pines. - Pacific Southwest Forest and Range Exp. Sta., U. S. Dept. Agr., Forest Service, Technical Bull. 1239. 158 pp.

Murto, J., 1951: Mäntypuumme pihka voiteluöljyn raaka-aineena. - Diss. 297 pp. Helsinki.

Norrman, J. \& N. Fries, 1967: The growth of Pestalotia rhododendri Guba in relation to volatile metabolites. - Arch. Mikrobiol. $56,330-343$.

Pridman, J. B., ed. 1967: Terpenoids in plants. 257 pp. New York - London.

Robinson, J. B. \& D. PARK, 1966: Volatile inhibitors of spore germination produced by fungi. - Trans. Brit. Mycol. Soc. 49, 639 -649 .

Schantz, Max von \& S. Juvonen, 1966 Chemotaxonomische Untersuchungen in der Gattung Picea. - Acta Bot. Fenn. 73, 1-51.

Shrimpton, D. M. \& H. S. Whitney, 1968: Inhibition of growth of blue stain fungi by wood extractives. - Can. J. Bot. 46, 757 -761 .

Smirnoff, W. A., 1968, Effects of volatile substances released by foliage of various plants on the entomopathogenic Bacillus cereus group. - J. Invert. Path. 11, 513-515.

Suolahtr, O., 1951: Über eine das Wachstum von Fäulnispilzen beschleuningende chemische Fernwirkung von Holz. - Diss. 95 pp. Helsinki.

Suvorov, P. A. 1967: Biologija okaimlennogo trutovika Fomes pinicola (Fr.) Cke. Byul. Mosk. obshchest. ispyt. prirody, Otd. biol. 1967, 72, 80-92. (cit. Biol. Abstr. 49,107690 ).

Thacker, D. G. \& M. Good, 1952: The composition of air in trunks of sugar maple in relation to decay. 